\title{
ANALISIS PENERAPAN PSAK NO.102 ATAS PEMBIAYAAN MURABAHAH PADA PT. BANK SYARIAH MANDIRI CABANG MANADO
}

\author{
Sri Wahyuni Muklis \\ Sifrid Sonny Pangemanan \\ Lidia Mawikere
}

Fakultas Ekonomi dan Bisnis Jurusan Akuntansi

Universitas Sam Ratulangi Manado

email : yhunie.muhlis@yahoo.com

\begin{abstract}
ABSTRAK
Produk pembiayaan murabahah adalah salah satu produk unggulan pembiayaan perbankan syariah. Ikatan Akuntansi Indonesia (IAI) telah menerbitkan Pernyataan Standar Akuntansi Keuangan (PSAK) No. 102 yang bertujuan untuk mengatur pengakuan, pengukuran, penyajian dan pengungkapan transaksi murabahah. Adapun tujuan dari penelitian ini adalah untuk mengetahui kesesuaian penerapan pembiayaan murabahah pada PT. Bank Syariah Mandiri Cabang Manado dengan PSAK No. 102. Jenis penelitian yang digunakan adalah jenis penelitian yang bersifat deskriptif, yaitu data yang telah dikumpulkan, kemudian disusun, diinterprestasikan, dan dianalisa sehingga memberikan keterangan yang lengkap atau gambaran yang sebenarnya tentang pembiayaan murabahah pada PT. Bank Syariah Mandiri Cabang Manado. Hasil penelitian ini menunjukkan bahwa penerapan perlakuan akuntansi pembiayaan murabahah pada PT. Bank Syariah Mandiri Cabang Manado dalam hal pengakuan, pengukuran, penyajian, dan pengungkapannya telah sesuai dengan Pernyataan Standar Akuntansi Keuangan No. 102.
\end{abstract}

Kata kunci: PSAK No. 102, Pembiayaan Murabahah.

\begin{abstract}
Funding product "Murabahah" is one of upscale for syariah banking. IAI (Indonesia Accountant Association) has published Accountant funding standard statement (PSAK) No. 102, which admission, transparency, measuring and explanation from "Murabahah" transaction. the other purpose from this research is to know adjustment of "Murabahah" in PT. Bank Syariah Mandiri, Manado Branch with PSAK No. 102. Descriptive theory is been used for this research, which is the data has been gathered, arranged, interpret, and analysed, so it can give full information or picture about "Murabahah" funding in PT. Bank Syariah Mandiri, Manado Branch, where this presentation has been standardized based from standard accountant funding statement No. 102.
\end{abstract}

Keywords: PSAK No. 102, Murabahah Funding. 


\subsection{Latar Belakang Masalah}

\section{PENDAHULUAN}

Kegiatan usaha yang paling dominan dan sangat dibutuhkan keberadaannya di dunia ekonomi saat ini adalah kegiatan usaha lembaga keuangan perbankan, oleh karena fungsinya sebagai pengumpul dana yang sangat berperan demi menunjang pertumbuhan ekonomi suatu bangsa. Lembaga keuangan perbankan merupakan lembaga keuangan yang bertugas menghimpun dana dari masyarakat dan menyalurkan kembali ke masyarakat guna memenuhi kebutuhan dana bagi pihak yang membutuhkan, baik untuk kegiatan produktif maupun konsumtif. (Ghaffar, 2009)

Lembaga perbankan di Indonesia telah terbagi menjadi dua jenis yaitu, bank yang bersifat konvensional dan bank yang bersifat syariah. Menurut Undang-Undang Nomor 20 tahun 2008, Bank Konvensional adalah bank yang menjalankan kegiatan usahanya secara konvensional dan berdasarkan jenisnya terdiri atas Bank Umum Konvensional dan Bank Perkreditan Rakyat. Sedangkan Bank Syariah adalah bank yang menjalankan kegiatan usahanya berdasarkan Prinsip Syariah dan menurut jenisnya terdiri atas Bank Umum Syariah dan Bank Pembiayaan Rakyat Syariah.

Perkembangan Bank Syariah di Indonesia mulai sangat terlihat. Tidak hanya Bank Muamalat Indonesia (BMI), saat ini mulai banyak berdirinya Bank Syariah sebagai cabang dari bank konvensional. Salah satunya yakni PT. Bank Syariah Mandiri yang secara resmi mulai beroperasi sejak Senin tanggal 25 Rajab 1420 H atau tanggal 1 November 1999. PT Bank Syariah Mandiri hadir, tampil dan tumbuh sebagai bank yang mampu memadukan idealisme usaha dengan nilai-nilai rohani, yang melandasi kegiatan operasionalnya. Harmoni antara idealisme usaha dan nilai-nilai rohani inilah yang menjadi salah satu keunggulan Bank Syariah Mandiri dalam kiprahnya di perbankan Indonesia. BSM hadir untuk bersama membangun Indonesia menuju Indonesia yang lebih baik.

Bank syariah mulai berkembang dalam skala besar dengan menawarkan berbagai produk pembiayaan dengan istilah-istilah yang masih belum dipahami oleh masyarakat pada umumnya. Pembiayaan merupakan salah satu kegiatan utama dan menjadi sumber utama pendapatan bagi bank syariah. Ada beberapa bentuk pembiayaan perbankan berdasarkan prinsip syariah, namun yang menjadi salah satu produk unggulan pembiayaan perbankan syariah adalah produk pembiayaan murabahah.

Kata al-Murabahah diambil dari bahasa Arab dari kata ar-ribhu ( ) yang berarti kelebihan dan tambahan (keuntungan). Sedangkan dalam definisi para ulama terdahulu adalah jual beli dengan modal ditambah keuntungan yang diketahui. Dalam buku Islamic Financial Management (2008: 145) definisi Murabahah adalah akad jual beli atas suatu barang, dengan harga yang disepakati antara penjual dan pembeli, setelah sebelumnya penjual menyebutkan dengan sebenarnya harga perolehan atas barang tersebut dan besarnya keuntungan yang diperolehnya.

Ikatan Akuntansi Indonesia (IAI) menerbitkan Pernyataan Standar Akuntansi Keuangan (PSAK) No. 102 yang bertujuan untuk mengatur pengakuan, pengukuran, penyajian dan pengungkapan transaksi murabahah yang diberlakukan secara efektif sejak tanggal 1 Januari 2008. Penerapan standar-standar akuntansi tersebut dapat menjaga konsistensi, baik yang bersifat internal maupun eksternal perusahaan, bahkan untuk menjamin kesesuaiannya dengan syariat islam. Dengan adanya standar yang ditetapkan mengenai pembiayaan murabahah, maka penulis merasa penting untuk membahas masalah akuntansi pembiayaan murabahah secara teori dengan meninjau penerapannya pada bank syariah. Untuk mengetahui kesesuaian penerapan pembiayaan murabahah yang telah diterapkan pada bank syariah dengan Pernyataan Standar Akuntansi Keuangan No. 102, mulai dari proses pengakuan, pengukuran sampai pada proses penyajian. Untuk itu penulis melakukan penelitian yang berjudul "Analisis Penerapan PSAK No. 102 atas Pembiayaan Murabahah Pada PT. Bank Syariah Mandiri Cabang Manado".

\subsection{Perumusan Masalah}

Berdasarkan latar belakang penelitian, maka penulis merumuskan masalah dalam bentuk pertanyaan yaitu : Apakah penerapan perlakuan akuntansi pembiayaan murabahah pada PT. Bank Syariah Mandiri Cabang Manado telah sesuai dengan PSAK No. 102 ?

\subsection{Tujuan Penelitian}

Penelitian ini bertujuan untuk mengetahui kesesuaian penerapan pembiayaan murabahah pada PT. Bank Syariah Mandiri Syariah Cabang Manado dengan PSAK No. 102. 


\subsection{Manfaat Penelitian}

Hasil penelitian ini diharapkan dapat memberi manfaat antara lain :

1.Bagi penulis yaitu sebagai bahan masukan untuk memperluas wawasan mengenai penerapan pembiayaan pada bank syariah, khususnya pembiayaan murabahah.

2.Bagi perusahaan yaitu sebagai bahan evaluasi dan penilaian bagi perusahaan mengenai akuntansi pembiayaan murabahah yang sudah diterapkan.

3. Bagi peneliti lain yaitu sebagai bahan masukan untuk menyempurnakan penulisan yang berhubungan dengan pembiayaan murabahah yang merupakan salah satu produk pembiayaan yang berlandaskan syariat islam.

\subsection{Akuntansi}

\section{TINJAUAN PUSTAKA}

Definisi akuntansi dari berbagai pendapat yaitu menurut American Insitute of Certified Public Accounting (AICPA) dalam Harahap (2012: 5) mendefinisikan akuntansi sebagai seni pencatatan, penggolongan, dan pengikhtisaran dengan cara tertentu dalam ukuran moneter, transaksi, dan kejadian-kejadian yang umumnya bersifat keuangan termasuk menafsirkan hasil-hasilnya. Definisi akuntansi yang dimuat dalam Accounting Terminology Bulletin No. 1 yang diterbitkan oleh Accounting Principles Board (APB) menyatakan bahwa akuntansi adalah seni pencatatan, penggolongan, dan peringkasan transaksi dan kejadian yang bersifat keuangan dengan cara yang berdaya guna dan dalam bentuk satuan uang, dan penginterpretasian hasil proses tersebut. (Suwardjono, 2013: 5)

\subsection{Akuntansi Konvensional}

Menurut Syahatah (2001: 94-95) akuntansi konvensional menganut sistem penilaian aktiva dan modal dengan prinsip historical cost dan membagi modal (aktiva) dalam dua golongan yakni, aktiva lancar (modal yang beredar) dan aktiva tetap (modal tetap). Konsep akuntansi konvensional mempraktikkan teori pencadangan dan ketelitian dari menanggung semua kerugian (conservatisme), dan mengabaikan laba-laba yang belum direalisasi. Akuntansi konvensional menerapkan laba secara menyeluruh, yang terdiri dari laba usaha, laba dari modal pokok, dan lain sebagainya.

\subsection{Akuntansi Syariah}

Akuntansi syariah adalah suatu kegiatan identifikasi, klasifikasi, dan pelaporan dalam mengambil keputusan ekonomi berdasarkan prinsip akad-akad syariah, yaitu tidak mengandung zhulum (Kezaliman), riba, maysir (judi), gharar (penipuan), barang yang haram dan membahayakan.

\subsection{Bank Syariah}

\subsubsection{Pengertian Bank Syariah}

Bank syariah dapat diartikan sebagai lembaga keuangan yang menghimpun dana dari masyarakat dan menyalurkannya kepada masyarakat berdasarkan prinsip-prinsip syariah islam yaitu berlandaskan Al-Qur'an dan Hadist. Bank syariah bertujuan untuk mempromosikan dan mengembangkan prinsip-prinsip islam, syariah dan tradisinya kedalam transaksi keuangan, perbankan, dan bisnis-bisnis lainnya yang berkaitan dengan keuangan.

\subsubsection{Prinsip-prinsip Umum Bank Syariah}

Dalam menjalankan usahanya, bank syariah harus tetap berpedoman pada nilai-nilai syariah. Prinsip itu berpedoman pada Al-quran dan Hadits. Prinsip yang diterapkan bank syariah meliputi :

1. Prinsip pengharaman riba

2. Prinsip keadilan

3. Prinsip kesamaan

\subsubsection{Ciri Bank Syariah}

Bank syariah mempunyai ciri-ciri sebagai berikut :

1. Dalam bank syariah, hubungan bank dengan nasabah adalah hubungan kontrak (akad) antara investor pemilik dana (shohibul maal) dengan investor pengelola dana (mudharib) bekerja sama untuk melakukan kerjasama untuk yang produktif dan sebagai keuntungan dibagi secara adil (mutual invesment relationship).

2. Adanya larangan-larangan kegiatan usaha tertentu oleh bank syariah yang bertujuan untuk menciptakan kegiatan perekonomian yang produktif (larangan menumpuk harta benda (sumber daya alam) yang 
dikuasai sebagian kecil masyarakat dan tidak produktif, menciptakan perekonomian yang adil (konsep usaha bagi hasil dan bagi resiko) serta menjaga lingkungan dan menjunjung tinggi moral (larangan untuk proyek yang merusak lingkungan dan tidak sesuai dengan nilai moral seperti minuman keras, sarana judi dan lain-lain.

3. Kegiatan usaha bank syariah lebih variatif dibanding bank konvensional, yaitu bagi hasil sistem jual beli, sistem sewa beli serta menyediakan jasa lain sepanjang tidak bertentangan dengan nilai dan prinsipprinsip syariah. (Kazuraoby, 2011)

\subsection{Pembiayaan}

\subsubsection{Pengertian Pembiayaan}

Menurut UU No. 10 tahun 1998 tentang Perbankan menyatakan pembiayaan berdasarkan prinsip syariah adalah penyediaan uang atau tagihan yang dipersamakan dengan itu berdasarkan persetujuan atau kesepakatan antara bank dengan pihak lain yang mewajibkan pihak yang dibiayai untuk mengembalikan uang atau tagihan tersebut setelah jangka waktu tertentu dengan imbalan atau bagi hasil.

\subsubsection{Unsur Pembiayaan}

Unsur-unsur dalam pembiayaan menurut Veithzal Riva \& Andria P Veithzal (2008: 4) yaitu :

1. Adanya dua pihak, yaitu pemberi pembiayaan (shahibul mal) dan penerima pembiayaan (mudharib).

2. Adanya kepercayaan shahibul mal kepada mudharib yang didasarkan atas prestasi dan potensi mudharib.

3. Adanya persetujuan, berupa kesepakatan pihak shahibul mal dengan pihak lainnya yang berjanji membayar dari mudharib kepada shahibul mal.

4. Adanya penyerahan barang, jasa atau uang dari shahibul mal kepada mudharib.

5. Adanya unsur waktu (time element). Unsur waktu merupakan unsur esensial pembiayaan.

6. Adanya unsur resiko (degree of risk) baik dipihak shahibul mal maupun dipihak mudharib.

\subsubsection{Produk Pembiayaan Syariah}

Secara garis besar produk pembiayaan syariah terbagi dalam empat kategori yang dibedakan berdasarkan tujuan penggunaanya yaitu: (Muhammad, dikutip dalam Budianas, 2013)

1. Pembiayaan dengan prinsip jual beli $\left(b a^{\prime} i\right)$, meliputi yaitu: pembiayaan murabahah, pembiayaan salam, dan pembiayaan istisna.

2. Pembiayaan dengan prinsip sewa, meliputi yaitu: pembiayaan ijarah dan pembiayaan Ijarah Muntahiya Biltamlik/Wa Iqtina.

3. Pembiayaan dengan prinsip bagi hasil, yang meliputi: pembiayaan mudharabah dan pembiayaan musyarakah.

4. Pembiayaan dengan akad pelengkap, yang meliputi: Hiwalah (Alih Hutang-Piutang), Rahn (Gadai), Qardh, Wakalah (Perwakilan), dan Kafalah (Garansi Bank).

\subsection{Murabahah}

Warsono Sony \& Jufri (2011: 48) menyatakan bahwa akad murabahah adalah akad jual beli barang dengan menyatakan harga asal dan keuntungan (margin) yang disepakati oleh penjual dan pembeli dimana pembayaran dapat dilakukan secara tunai atau tangguh (kredit).

\subsection{Akuntansi Murabahah Berdasarkan PSAK No.102}

\subsubsection{Pengertian Murabahah}

Pengertian murabahah menurut IAI (PSAK No.102, 2007: Akuntansi Murabahah, paragraph 05) adalah akad jual beli barang dengan harga jual sebesar biaya perolehan ditambah keuntungan yang disepakati dan penjual harus mengungkapkan biaya perolehan barang tersebut kepada pembeli.

\subsubsection{Karakteristik Murabahah}

Murabahah dapat dilakukan berdasarkan pesanan atau tanpa pesanan. Dalam murabahah berdasarkan pesanan, penjual melakukan pembelian barang setelah ada pemesanan dari pembeli. Pembayaran murabahah dapat dilakukan secara tunai atau tangguh. Pembayaran tangguh adalah pembayaran yang dilakukan tidak pada saat barang diserahkan kepada pembeli, tetapi pembayaran dilakukan secara angsuran atau sekaligus pada waktu tertentu.

\subsection{Penelitian Terdahulu}

Asmahani Mukhtar Ghaffar (2009) dengan judul Penerapan PSAK no. 102 tentang pembiayaan murabahah pada PT. Bank Syariah Mandiri Cabang Medan. Masita, Jamaluddin \& Musviyanti (2013) dengan 
judul Analisis penerapan pernyataan standar akuntansi keuangan (PSAK) nomor 102 (studi kasus pada Pegadaian Syariah Cabang Gunung Sari Balikpapan.

\subsection{Jenis Penelitian}

\section{METODE PENELITIAN}

Jenis penelitian yang digunakan adalah jenis penelitian yang bersifat deskriptif. Menurut Mudrajad Kuncoro (2009: 12) tipe yang paling umum dari penelitian deskriptif meliputi penilaian sikap atau pendapat terhadap individu, organisasi, keadaan, ataupun prosedur. Data deskriptif pada umumnya dikumpulkan melalui daftar pertanyaan dalam survey, wawancara ataupun observasi. Data yang telah dikumpulkan, kemudian disusun, diinterprestasikan, dan dianalisa sehingga memberikan keterangan yang lengkap atau gambaran yang sebenarnya tentang pembiayaan murabahah pada PT. Bank Syariah Mandiri Cabang Manado.

\subsection{Tempat dan Waktu Penelitian}

Penelitian dilaksanakan pada Bank Syariah Mandiri Cabang Manado, Jl. Piere Tendean, Kompleks Ruko Mega Mas, Blok D1 No. 28, Boulevard Manado, 95115. Nomor Telepon (0431) 879553, 879444 dan nomor fax (0431) 879492. Waktu penelitian dimulai pada kegiatan pembuatan proposal pada bulan Agustus sampai September 2013 sedangkan untuk kegiatan penelitian dimulai bulan Oktober 2013 pada PT. Bank Syarah Mandiri Cabang Manado.

\subsection{Prosedur Penelitian}

Prosedur penelitin terdiri atas beberapa tahapan sebagai berikut :

a) Mengajukan permohonan penelitian dengan memasukkan surat penelitian yang telah disetujui dari Fakultas Ekonomi dan Bisnis Universitas Sam Ratulangi untuk melakukan penelitian pada objek PT. Bank Syariah Mandiri Cabang Manado.

b) Tindak lanjut dari pihak bank, dalam hal ini surat penelitian disahkan oleh Kepala Cabang yang berarti pihak bank telah memberi izin persetujuan penelitian pada PT. Bank Syariah Mandiri Cabang Manado.

c) Mulai mengumpulkan data dengan melakukan wawancara pada Bagian PMS (Pelaksana Marketing Support) dan Bagian Administrasi Warung Mikro.

d) Menganalisis data yang akan dipakai sesuai dengan rumusan masalah pada penelitian untuk melengkapi dan menentukan hasil penelitian.

e) Menganalisis dan mengolah data yang diperoleh dari perusahaan.

f) Melakukan perbandingan untuk mengetahui kesesuaian data pada bank dengan PSAK No. 102.

g) Menarik kesimpulan dari hasil data yang telah dibandingkan dengan PSAK No.102 dan memberikan saran.

\subsection{Metode Pengumpulan Data}

\subsubsection{Jenis Data}

Jenis data yang digunakan penulis adalah data kualitatif. Menurut Supriyanto (2009: 133) data kualitatif merupakan data berupa kata-kata atau kalimat dan biasanya bersifat menggolongkan atau klasifikasi. Data kualitatif ini berasal dari hasil wawancara sekilas tentang pembiayaan murabahah pada PT. Bank Syariah Mandiri Cabang Manado.

\subsubsection{Sumber Data}

Sumber data yang digunakan penulis, menurut supriyanto (2009: 133) yaitu :

1) Data primer adalah data yang dikumpulkan dan diolah sendiri oleh peneliti langsung dari responden. Data primer penelitian ini diperoleh melalui hasil wawancara terhadap staff yang bersangkutan yaitu dibagian PMS (Pelaksana Marketing Support) dan Administrasi Warung Mikro.

2) Data sekunder adalah data yang diperoleh dalam bentuk sudah jadi, yaitu: diolah dan disajikan oleh pihak lain. Teknik pengumpulannya dilakukan dengan dokumentasi. Jadi data yang diperoleh peneliti melalui penelusuran catatan dan dokumen resmi perusahaan, misalnya: sejarah singkat perusahaan, struktur organisasi, laporan keuangan bank syariah serta literature yang berhubungan dengan tujuan penelitian.

\subsubsection{Teknik Pengumpulan Data}

Teknik pengumpulan data yang digunakan dalam penelitian ini yakni :

a. Wawancara, yaitu melakukan wawancara yang berupa pertanyaan-pertanyaan yang berhubungan dengan permasalahan secara langsung dengan pihak yang berwenang didalam perusahaan untuk memperoleh informasi dan mengumpulkan data yang berhubungan dengan pembiayaan murabahah yang diterapkan 
oleh perusahaan. Menurut Restu Kartiko Widi (2010: 236), wawancara dapat sangat fleksibel atau bebas ketika pewawancara mempunyai kebebasan menyusun pertanyaan yang ada dalam benaknya disekitar permasalahan yang hendak diteliti. Dalam hal ini, peneliti melakukan wawancara pada bagian PMS (Pelaksana Marketing Support) dan Administrasi Warung Mikro di PT. Bank Syariah Mandiri Cabang Manado.

b. Dokumentasi, merupakan cara untuk memperoleh data langsung di tempat penelitian yang diperoleh melalui buku-buku, peraturan-peraturan, laporan relevan yang ada pada objek penelitian. Data yang diperoleh biasanya berupa data sekunder. Dalam hal ini, peneliti tinggal mengambil data yang telah diolah oleh pihak lain. Atau dilakukan dengan menyalin data atau dokumen yang dihasilkan oleh pihak lain. (Supriyanto, 2009: 137)

\subsection{Metode Analisis Data}

Dengan metode deskriptif maka teknik analisa data dilakukan melalui tahap-tahap sebagai berikut:

1) Reduksi data, yaitu proses pemilihan dan penyederhanaan data-data yang muncul dari catatan-catatan tertulis. Data yang direduksi mulai dari gambaran perusahaan dan mengenai pembiayaan murabahah pada perusahaan.

2) Penyajian data, yaitu penyusunan informasi yang kompleks kedalam suatu bentuk yang sistematis, sehingga menjadi lebih selektif dan sederhana serta memberikan kemungkinan adanya penarikan kesimpulan data. Data yang disajikan berupa gambaran perusahaan, struktur organisasi, prosedur pembiayaan murabahah, dan laporan keuangan.

3) Data-data yang telah ada kemudian dibandingkan dengan Pernyataan Standar Akuntansi Keuangan No. 102 yang berkaitan dengan pengakuan, pengukuran, penyajian, dan pengungkapan transaksi murabahah.

4) Menganalisa hasil dari perbandingan PSAK No. 102 dengan data yang diperoleh dari perusahaan.

5) Menarik kesimpulan, yaitu merupakan tahap akhir dalam proses analisa data. Pada bagian ini peneliti mengutarakan kesimpulan dari data-data yang telah diperoleh dari wawancara dan dokumentasi. Kemudian mengambil kesimpulan dari hasil data yang telah dibandingkan dengan PSAK No.102.

\subsection{Gambaran Perusahaan}

\section{HASIL PENELITIAN DAN PEMBAHASAN}

Pada tanggal 25 Oktober 1999, Bank Indonesia melalui Surat Keputusan Gubernur Bank Indonesia No. 1/24/KEP. BI/1999 telah memberikan ijin perubahan kegiatan usaha konvensional menjadi kegiatan usaha berdasarkan prinsip syariah kepada PT. Bank Susila Bakti. Selanjutnya dengan Surat Keputusan Deputi Gubernur Senior Bank Indonesia No. 1/1/KEP.DGS/1999 tanggal 25 Oktober 1999, Bank Indonesia telah menyetujui perubahaan nama PT. Bank Susila Bakti menjadi PT. Bank Syariah Mandiri. Senin tanggal 25 Rajab $1420 \mathrm{H}$ atau tanggal 1 November 1999 merupakan hari pertama beroperasinya PT. Bank Syariah Mandiri. PT. Bank Syariah Mandiri sebagai bank syariah terbesar dengan jaringan terluas di Tanah Air memiliki 169 outlet yang tersebar di 23 provinsi di Indonesia. Untuk di wilayah Provinsi Sulawesi Utara, PT. Bank Syariah Mandiri mulai beroperasi sejak tanggal 25 Februari 2005 dengan pembukaan kantor cabangnya di Kota Manado.

\subsection{Hasil Penelitian}

\subsubsection{Penerapan Pembiayaan Murabahah pada BSM Cabang Manado}

Pada transaksi murabahah, nasabah akan mengajukan permohonan fasilitas pembiayaan kepada bank untuk membeli barang. Sebelum melakukan jual beli barang, pihak bank akan melakukan negosiasi terlebih dahulu dengan nasabah untuk jenis barang, kualifikasi barang, harga barang serta cara pembayarannya. Setelah ada kesepakatan, bank menghubungi pemasok barang yang akan dibeli dan melakukan pembelian barang sesuai dengan permintaan nasabah. Barang yang diperoleh dari pemasok diakui sebagai persediaan sebesar harga perolehannya.

Nasabah membayar harga pokok, biaya-biaya lain atas jual beli, dan ditambah margin keuntungan kepada bank dalam jangka waktu tertentu yang disepakati oleh kedua belah pihak, sehingga karenanya sebelum nasabah membayar lunas kepada bank, nasabah berutang kepada bank. Jadi, Piutang murabahah diakui sebesar biaya perolehan ditambah dengan keuntungan yang disepakati. Biasanya uang muka yang akan dibayar nasabah yaitu sekitar 10\% - 30\% yang menjadi bagian pembayaran piutang atas murabahah yang dilakukan. Pembayaran uang muka oleh nasabah bertujuan untuk membantu pihak bank agar dapat memperoleh barang murabahah secara lancar. 
Jangka waktu pembiayaan yang diberikan oleh BSM yaitu maksimal 15 tahun untuk pembiayaan pemilikan rumah, 5 tahun untuk pembiayaan pemilikan mobil, dan maksimal 4 tahun untuk jumlah pembiayaan yang relatif kecil. Besarnya margin yang ditetapkan untuk pembiayaan murabahah adalah $7 \%$ sampai dengan 8\%/ tahun. Dan 28\% sampai dengan 32\%/ tahun untuk jumlah pembiayaan yang relatif kecil. Apabila terjadi keterlambatan pembayaran oleh nasabah kepada bank, maka nasabah akan dikenakan denda berupa biaya administrasi pada bank sebesar 0,00069 x nominal angsuran (perhari) untuk tiap-tiap hari keterlambatan yang terhitung sejak saat kewajiban pembayaran tersebut jatuh tempo sampai dengan tanggal dilaksanakannya pembayaran kembali.

Untuk menjamin tertibnya pembayaran kembali/pelunasan pembiayaan dan margin keuntungan tepat pada waktu yang telah disepakati kedua belah pihak, maka nasabah berkewajiban untuk menyerahkan jaminan berupa sertifikat hak milik ataupun BPKB. Adapun biaya-biaya yang dikenakan kepada nasabah berkaitan dengan pembiayaan murabahah yaitu biaya administrasi $1 \%$ dari plafond, biaya notaris, biaya asuransi, biaya jaminan dan sebagainya.

Nasabah yang menunda pembayaran sampai batas waktu yang ditentukan akan mendapat denda atas keterlambatan pembayaran. Jika nasabah pailit dan tidak mampu membayar, pihak bank akan memberi masa tenggang waktu sesuai kesepakatan dan melakukan langkah-langkah seperti restrukturisasi. Dan jika nasabah masih tidak mampu membayar sesuai kesepakatan maka bank akan menarik kembali barang yang telah dibiayai dan menjual barang tersebut untuk menutupi sisa utang nasabah. Kelebihan ataupun kekurangan dari penjualan barang tersebut akan diberikan kepada nasabah.

Bila nasabah tidak mengalami kesulitan dana dan mempercepat proses pembayaran angsuran tiap bulan, maka nasabah akan diberi discount/potongan oleh bank. Potongan tersebut sering disebut dengan discount margin dan diakui sebagai pengurang pendapatan margin murabahah. Dalam hal pengakuan pendapatan margin yang diperoleh, bank menggunakan dasar kas (cash basis) yang besarnya jumlah pendapatan margin diakui proporsional dengan besaran kas yang berhasil ditagih dari piutang murabahah. Dengan kata lain pendapatan margin diakui sebesar kas yang berhasil ditagih atau dibayar oleh nasabah yaitu persentase keuntungan dikalikan dengan jumlah piutang nasabah.

\subsubsection{Prosedur Pembiayaan Murabahah}

Prosedur awal yang ditempuh oleh calon nasabah untuk memperoleh persetujuan pembiayaan adalah :

1) Calon nasabah mengajukan permohonan pembiayaan murabahah yang dibuat langsung oleh calon nasabah dengan melampirkan fotocopy KTP.

2) Dengan KTP calon nasabah, Account Officer (AO) melakukan penilaian pembiayaan untuk mengetahui layak tidaknya suatu pembiayaan disalurkan.

3) AO melakukan interview awal dengan calon nasabah untuk memperoleh informasi mengenai calon nasabah, penyelidikan tentang tujuan penggunaan pembiayaan, kunjungan ke lokasi jaminan calon nasabah untuk mengetahui kebenarannya dan menilai jaminan, penilaian atas legalitas usaha dan untuk mengetahui gambaran umum mengenai kemampuan keuangan calon nasabah.

4) Setelah memperoleh keyakinan atas keabsahan dokumen dari hasil penyelidikan dan wawancara maka langkah selanjutnya adalah memberikan keputusan, menerima atau menolak pembiayaan tersebut. Bila telah dianggap layak menerima pembiayaan, maka persetujuan pembiayaan diberikan oleh AO, yang dituangkan dalam Nota Analisa Pembiayaan (NAP).

5) Selanjutnya NAP akan diajukan oleh AO kepada Pimpinan Cabang untuk meminta persetujuan pembiayaan. Jika pimpinan Cabang menyetujui pembiayaan tersebut maka akan dinyatakan dalam Surat Keputusan Pembiayaan (SKP) yang telah dibuat oleh Administrasi Pembiayaan.

6) Tahap selanjutnya adalah proses pencairan dana atas permohonan pembiayaan yang telah disetujui oleh Pimpinan Cabang. NAP, SKP dan dokumen lainnya akan diserahkan kepada Administrasi Pembiayaan untuk selanjutnya dibuat SP3/akad pembiayaan.

7) Tahap selanjutnya adalah pencairan pembiayaan. Dana yang diberikan sesuai dengan jumlah yang disetujui dalam akad perjanjian pembiayaan murabahah yang akan langsung ditransfer ke dalam rekening nasabah yang ada di BSM cabang manado.

8) AO melakukan monitoring yang meliputi pemantauan langsung ke tempat usaha, pemeriksaan laporan keuangan maupun perkembangan nilai jaminannya.

9) AO mengontrol perkembangan usaha nasabah dan melakukan evaluasi atas perkembangan usaha yang dibiayai berdasarkan data-data yang diperoleh dari riwayat pembayaran nasabah dan data-data yang ada dalam file pembiayaan. 
10) Tahap terakhir yaitu melakukan penutupan pembiayaan murabahah nasabah dengan melunasi seluruh pembiayaan yang telah disepakati. Kemudian AO melakukan pemeriksaan melalui data yang ada pada komputer untuk melihat kebenaranya. Jika nasabah telah melunasi seluruh pembiayaan, maka Administrasi Pembiayaan akan membuat surat pelunasan yang harus disetujui oleh Pimpinan Cabang. Bila Pimpinan Cabang telah menyetujui surat pelunasan tersebut, maka ia akan memberikan surat perintah kepada Unit Kontrol intern untuk mengeluarkan jaminan nasabah.

11) AO menyerahkan dokumen jaminan dan Surat Pelunasan Pembiayaan kepada nasabah dan nasabah menadatangani tanda terima dokumen. Kemudian tanda terima pelepasan jaminan diarsipkan oleh Asisten Administrasi Pembiayan. Tanda terima jaminan ini berfungsi sebagai bukti bahwa dokumen jaminan telah diambil oleh nasabah.

\subsection{Pembahasan}

Untuk mengetahui kesesuaian penerapan pembiayaan murabahah pada PT. Bank Syariah Mandiri Cabang Manado dengan Pernyataan Standar Akuntansi Keuangan No. 102, maka dapat dilihat pada tabel-tabel analisis perbandingan antara PSAK No. 102 dan PT. Bank Syariah Mandiri Cabang Manado tentang pengakuan dan pengukuran serta penyajian dan pengungkapan sebagai berikut :

a) Perbadingan pengakuan dan pengukuran pada aktiva (asset) murabahah.

Tabel 4.1 perbandingan antara PT. Bank Syariah Mandiri Cabang Manado dan PSAK No. 102 tentang Pengakuan dan Pengukuran pada aktiva (asset) murabahah.

\begin{tabular}{|l|l|l|c|}
\hline & \multicolumn{1}{|c|}{$\begin{array}{c}\text { PT. Bank Syariah Mandiri } \\
\text { Cabang Manado }\end{array}$} & \multicolumn{1}{c|}{ PSAK No.102 } & (Sesuai) \\
Aktiva (aset) & $\begin{array}{l}\text { Setelah ada kesepakatan, bank } \\
\text { menghubungi pemasok barang yang } \\
\text { akan dibeli dan melakukan pembelian }\end{array}$ & $\begin{array}{l}\text { Pada saat perolehan, aset murabahah } \\
\text { diakui sebagai persediaan sebesar biaya } \\
\text { perolehan (paragraf 18) }\end{array}$ & \\
& $\begin{array}{l}\text { barang sesuai dengan permintaan } \\
\text { nasabah. Barang yang diperoleh dari } \\
\text { pemasok diakui sebagai persediaan }\end{array}$ & & \\
& sebesar harga perolehannya. & & \\
\hline
\end{tabular}

Sumber : Data diolah, 2013

Pada tabel 4.1 dapat dilihat bahwa penerapan pembiayaan murabahah dalam hal pengakuan dan pengukuran pada aktiva (asset) murabahah telah sesuai dengan PSAK No. 102 pada paragraf 18 yang menyatakan bahwa asset murabahah diakui sebagai persediaan sebesar biaya perolehan.

b) Perbandingan pengakuan dan pengukuran pada piutang murabahah.

Tabel 4.2 perbandingan antara PT. Bank Syariah Mandiri Cabang Manado dan PSAK No. 102 tentang Pengakuan dan Pengukuran pada piutang murabahah.

\begin{tabular}{|c|c|c|c|}
\hline & $\begin{array}{l}\text { PT. Bank Syariah Mandiri } \\
\text { Cabang Manado }\end{array}$ & PSAK No.102 & Keterangan \\
\hline $\begin{array}{l}\text { Piutang } \\
\text { Murabahah }\end{array}$ & $\begin{array}{l}\text { Nasabah membayar harga pokok dan } \\
\text { biaya-biaya lain atas jual beli ditambah } \\
\text { margin keuntungan kepada bank. Jadi, } \\
\text { Piutang murabahah diakui sebesar biaya } \\
\text { perolehan ditambah dengan keuntungan } \\
\text { yang disepakati. }\end{array}$ & $\begin{array}{l}\text { Pada saat akad murabahah, piutang } \\
\text { murabahah diakui sebesar biaya perolehan } \\
\text { aset murabahah ditambah keuntungan yang } \\
\text { disepakati (paragraf 22) }\end{array}$ & (Sesuai) \\
\hline
\end{tabular}

Sumber : Data diolah, 2013

Pada tabel 4.2 dapat dilihat bahwa penerapan pembiayaan murabahah dalam hal pengakuan dan pengukuran pada piutang murabahah telah sesuai dengan PSAK No. 102 pada paragraf 22 yang menyatakan bahwa piutang murabahah diakui sebesar biaya perolehan aset murabahah ditambah keuntungan yang disepakati.

c) Perbandingan pengakuan dan pengukuran pada pendapatan margin murabahah. 
Tabel 4.3 perbandingan antara PT. Bank Syariah Mandiri Cabang Manado dan PSAK No. 102 tentang Pengakuan dan Pengukuran pada pendapatan margin murabahah.

\begin{tabular}{|c|c|c|c|}
\hline & $\begin{array}{l}\text { PT. Bank Syariah Mandiri } \\
\text { Cabang Manado }\end{array}$ & PSAK No.102 & Keterangan \\
\hline $\begin{array}{l}\text { Pendapatan } \\
\text { Margin } \\
\text { Murabahah }\end{array}$ & $\begin{array}{l}\text { Besarnya margin yang ditetapkan untuk } \\
\text { pembiayaan murabahah adalah } 7 \% \\
\text { sampai dengan } 8 \% \text { tahun. Dan } \\
28 \% \text { sampai dengan } 32 \% / \text { tahun untuk } \\
\text { jumlah pembiayaan yang relative kecil. } \\
\text { Pendapatan margin diakui sebesar kas } \\
\text { yang berhasil ditagih atau dibayar oleh } \\
\text { nasabah yaitu persentase keuntungan } \\
\text { dikalikan dengan jumlah piutang } \\
\text { nasabah. }\end{array}$ & $\begin{array}{l}\text { Dalam mengakui pendapatan margin atau } \\
\text { keuntungan terdapat beberapa metode } \\
\text { salah satunya yaitu: keuntungan diakui } \\
\text { proporsional dengan besaran kas yang } \\
\text { berhasil ditagih dari piutang murabahah } \\
\text { (paragraf 23) }\end{array}$ & (Sesuai) \\
\hline
\end{tabular}

Sumber : Data diolah, 2013

Pada tabel 4.3 dapat dilihat bahwa penerapan pembiayaan murabahah dalam hal pengakuan dan pengukuran pada pendapatan margin murabahah telah sesuai dengan PSAK No. 102 pada paragraf 23 yang menyatakan bahwa pendapatan margin murabahah diakui proporsional dengan besaran kas yang berhasil ditagih dari piutang murabahah.

d) Perbandingan pengakuan dan pengukuran pada potongan murabahah.

Tabel 4.4 perbandingan antara PT. Bank Syariah Mandiri Cabang Manado dan PSAK No. 102 tentang Pengakuan dan Pengukuran pada potongan murabahah.

\begin{tabular}{|c|c|c|c|}
\hline & $\begin{array}{l}\text { PT. Bank Syariah Mandiri } \\
\text { Cabang Manado }\end{array}$ & PSAK No.102 & Keterangan \\
\hline $\begin{array}{l}\text { Potongan } \\
\text { Murabahah }\end{array}$ & $\begin{array}{l}\text { Bila nasabah tidak mengalami kesulitan } \\
\text { dana dan mempercepat proses } \\
\text { pembayaran angsuran tiap bulan, maka } \\
\text { nasabah akan diberi discount/potongan } \\
\text { oleh bank. Potongan tersebut sering } \\
\text { disebut dengan discount margin dan } \\
\text { diakui sebagai pengurang pendapatan } \\
\text { margin murabahah. }\end{array}$ & $\begin{array}{l}\text { Potongan pelunasan piutang murabahah } \\
\text { yang diberikan kepada pembeli yang } \\
\text { melunasi secara tepat waktu atau lebih } \\
\text { cepat dari waktu yang disepakati diakui } \\
\text { sebagai pengurang keuntungan } \\
\text { murabahah (paragraf 26) }\end{array}$ & (Sesuai) \\
\hline
\end{tabular}

Sumber : Data diolah, 2013

Pada tabel 4.4 dapat dilihat bahwa penerapan pembiayaan murabahah dalam hal pengakuan dan pengukuran pada potongan murabahah telah sesuai dengan PSAK No. 102 pada paragraf 26 yang menyatakan bahwa potongan pelunasan piutang murabahah yang diberikan kepada pembeli yang melunasi secara tepat waktu atau lebih cepat dari waktu yang disepakati diakui sebagai pengurang keuntungan murabahah.

e) Perbandingan pengakuan dan pengukuran pada denda atas pembiayaan murabahah.

Tabel 4.5 perbandingan antara PT. Bank Syariah Mandiri Cabang Manado dan PSAK No. 102 tentang Pengakuan dan Pengukuran pada denda atas pembiayaan murabahah.

\begin{tabular}{|c|c|c|c|}
\hline & $\begin{array}{l}\text { PT. Bank Syariah Mandiri } \\
\text { Cabang Manado }\end{array}$ & PSAK No.102 & Keterangan \\
\hline Denda & $\begin{array}{l}\text { Apabila terjadi keterlambatan } \\
\text { pembayaran oleh nasabah kepada bank, } \\
\text { maka nasabah akan dikenakan denda } \\
\text { berupa biaya administrasi pada bank } \\
\text { sebesar 0,00069 x nominal angsuran } \\
\text { (perhari) untuk tiap-tiap hari } \\
\text { keterlambatan yang terhitung sejak saat } \\
\text { kewajiban pembayaran tersebut jatuh } \\
\text { tempo sampai dengan tanggal } \\
\text { dilaksanakannya pembayaran kembali. }\end{array}$ & $\begin{array}{l}\text { Denda dikenakan jika pembeli lalai dalam } \\
\text { melakukan kewajibannya sesuai dengan } \\
\text { akad, dan denda yang diterima diakui } \\
\text { sebagai bagian danak kebajikan (paragraf } \\
\text { 29) }\end{array}$ & (Sesuai) \\
\hline
\end{tabular}

Sumber : Data diolah, 2013 
Pada tabel 4.5 dapat dilihat bahwa penerapan pembiayaan murabahah dalam hal pengakuan dan pengukuran pada denda murabahah telah sesuai dengan PSAK No. 102 pada paragraf 29 yang menyatakan bahwa denda dikenakan jika pembeli lalai dalam melakukan kewajibannya sesuai dengan akad, dan denda yang diterima diakui sebagai bagian danak kebajikan.

f) Perbandingan pengakuan dan pengukuran pada uang muka atas pembiayaan murabahah.

Tabel 4.6 perbandingan antara PT. Bank Syariah Mandiri Cabang Manado dan PSAK No. 102 tentang Pengakuan dan Pengukuran pada Uang Muka atas pembiayaan murabahah.

\begin{tabular}{|l|l|l|c|}
\hline & \multicolumn{1}{|c|}{$\begin{array}{c}\text { PT. Bank Syariah Mandiri } \\
\text { Cabang Manado }\end{array}$} & \multicolumn{1}{c|}{ PSAK No.102 } & Keterangan \\
\hline Uang & $\begin{array}{l}\text { Biasanya uang muka yang akan dibayar } \\
\text { Muka }\end{array}$ & $\begin{array}{l}\text { Uang muka diakui sebagai uang muka } \\
\text { menjadi bagian pembayaran piutang atas }\end{array}$ & (Sesuai) \\
& $\begin{array}{l}\text { membelian sebesar jumlah yang diterima, } \\
\text { Jurabahah yang dilakukan. }\end{array}$ & $\begin{array}{l}\text { maka uang jadi dibeli oleh pembeli, } \\
\text { pembayaran piutang (merupakan bagian } \\
\text { pokok). (paragraf 30) }\end{array}$ & \\
& & diakui sebagai & \\
\hline
\end{tabular}

Sumber : Data diolah, 2013

Pada tabel 4.6 dapat dilihat bahwa penerapan pembiayaan murabahah dalam hal pengakuan dan pengukuran pada uang muka murabahah telah sesuai dengan PSAK No. 102 pada paragraf 30 yang menyatakan bahwa uang muka diakui sebagai uang muka pembelian sebesar jumlah yang diterima, Jika barang jadi dibeli oleh pembeli, maka uang muka diakui sebagai pembayaran piutang.

g) Perbandingan penyajian dan pengungkapan pada piutang murabahah.

Tabel 4.7 perbandingan antara PT. Bank Syariah Mandiri Cabang Manado dan PSAK No. 102 tentang Penyajian dan Pengungkapan pada piutang murabahah.

Sumber : Data diolah, 2013

\begin{tabular}{|c|c|c|c|}
\hline & $\begin{array}{l}\text { PT. Bank Syariah Mandiri } \\
\text { Cabang Manado }\end{array}$ & PSAK No. 102 & Keterangan \\
\hline $\begin{array}{l}\text { Piutang } \\
\text { Murabahah }\end{array}$ & $\begin{array}{l}\text { Piutang murabahah pada PT. BSM } \\
\text { Cabang Syariah disajikan dilaporan } \\
\text { neraca sebesar saldo piutang murabahah } \\
\text { dikurangi dengan penyisihan piutang } \\
\text { murabahah. }\end{array}$ & $\begin{array}{l}\text { Piutang murabahah disajikan sebesar } \\
\text { nilai bersih yang dapat direalisasikan, } \\
\text { yaitu saldo piutang murabahah dikurangi } \\
\text { penyisihan kerugian piutang (paragraf } 37 \text { ) }\end{array}$ & ( Sesuai ) \\
\hline
\end{tabular}

Pada tabel 4.7 dapat dilihat bahwa penerapan pembiayaan murabahah dalam hal penyajian dan pengungkapan pada piutang murabahah telah sesuai dengan PSAK No. 102 pada paragraf 37 yang menyatakan bahwa piutang murabahah disajikan sebesar nilai bersih yang dapat direalisasikan, yaitu saldo piutang murabahah dikurangi penyisihan kerugian piutang.

h) Perbandingan penyajian dan pengungkapan pada margin murabahah yang ditangguhkan.

Tabel 4.8 perbandingan antara PT. Bank Syariah Mandiri Cabang Manado dan PSAK No. 102 tentang Penyajian dan Pengungkapan pada margin murabahah yang ditangguhkan.

\begin{tabular}{|c|c|c|c|}
\hline & $\begin{array}{c}\text { PT. Bank Syariah Mandiri } \\
\text { Cabang Manado }\end{array}$ & PSAK No. 102 & Keterangan \\
\hline $\begin{array}{l}\text { Margin } \\
\text { Murabahah } \\
\text { yang } \\
\text { ditangguhkan }\end{array}$ & $\begin{array}{l}\text { Margin murabahah yang ditangguhkan } \\
\text { pada PT. BSM Cabang Manado } \\
\text { disajikan dilaporan neraca sebagai } \\
\text { pengurang piutang murabahah. Cara } \\
\text { penyajiannya sama dengan penyajian } \\
\text { akumulasi depresiasi aset tetap. Margin } \\
\text { murabahah yang ditangguhkan akan } \\
\text { berkurang apabila telah jatuh tempo atau } \\
\text { dibayar. }\end{array}$ & $\begin{array}{l}\text { Margin murabahah tangguhan disajikan } \\
\text { sebagai pengurang (contra account) } \\
\text { piutang Murabahah (paragraf } 38)\end{array}$ & ( Sesuai ) \\
\hline
\end{tabular}

Sumber : Data diolah, 2013 
Pada tabel 4.8 dapat dilihat bahwa penerapan pembiayaan murabahah dalam hal penyajian dan pengungkapan pada margin murabahah yang ditangguhkan telah sesuai dengan PSAK No. 102 pada paragraf 38 yang menyatakan bahwa margin murabahah ditangguhan disajikan sebagai pengurang piutang murabahah.

i) Perbandingan penyajian dan pengungkapan pada pendapatan margin murabahah.

Tabel 4.9 perbandingan antara PT. Bank Syariah Mandiri Cabang Manado dan PSAK No. 102 tentang Penyajian dan Pengungkapan pada pendapatan margin murabahah.

\begin{tabular}{|l|l|l|c|}
\hline & \multicolumn{1}{|c|}{$\begin{array}{c}\text { PT. Bank Syariah Mandiri } \\
\text { Cabang Manado }\end{array}$} & PSAK No. 102 & Keterangan \\
\hline $\begin{array}{l}\text { Pendapatan } \\
\text { Margin }\end{array}$ & $\begin{array}{l}\text { Pendapatan margin murabahah } \\
\text { disajikan di laporan laba rugi pada } \\
\text { bagian pendapatan. }\end{array}$ & $\begin{array}{l}\text { Pengungkapan yang dilakukan sesuai } \\
\text { dengan PSAK 101 paragraf 11 tentang } \\
\text { penyajian laporan keuangan syariah yang } \\
\text { meliputi neraca, laporan laba rugi, laporan } \\
\text { arus kas, laporan perubahan ekuitas, } \\
\text { laporan penggunaan dana zakat, laporan } \\
\text { sumber dan penggunaan dana kebajikan, } \\
\text { catatan atas laporan keuangan. }\end{array}$ & \\
\hline
\end{tabular}

Sumber : Data diolah, 2013

Pada tabel 4.9 dapat dilihat bahwa penerapan pembiayaan murabahah dalam hal penyajian dan pengungkapan pada pendapatan margin murabahah telah sesuai dengan PSAK No. 102 yaitu pendapatan margin murabahah disajikan dilaporan laba rugi pada bagian pendapatan yang diakui dengan besaran kas yang berhasil ditagih dari piutang murabahah.

\subsection{Kesimpulan}

\section{PENUTUP}

Berdasarkan hasil analisa dan pembahasan dapat ditarik kesimpulan sebagai berikut :

a. Dalam hal pengakuan dan pengukuran pembiayaan murabahah yang diterapkan pada PT. Bank Syariah Mandiri Cabang Manado telah sesuai dengan Pernyataan Standar Akuntansi Keuangan No. 102.

b. Dalam hal panyajian dan pengungkapan pembiayaan murabahah yang diterapkan pada PT. Bank Syariah Mandiri Cabang Manado telah sesuai dengan Pernyataan Standar Akuntansi Keuangan No. 102.

\subsection{Saran}

Berdasarkan kesimpulan diatas menyatakan bahwa penerapan perlakuan akuntansi pembiayaan murabahah pada PT. Bank Syariah Mandiri Cabang Manado telah sesuai dengan Pernyataan Standar Akuntansi Keuangan No. 102 . Penulis berharap sistem dalam pembiayaan murabahah tersebut dapat dipertahankan. Saran dari penulis agar untuk penelitian selanjutnya pihak bank bisa lebih terbuka mengenai data laporan keuangan yang ada pada bank tersebut.

\section{DAFTAR PUSTAKA}

Budianas, Nanang, 2013. Pengertian Pembiayaan dan Jenis-Jenis Pembiayaan Bank Syariah. http://nanangbudianas.blogspot.com/2013/02/pengertian-pembiayaan-dan-jenis-jenis.html. Diakses February, 08, 2013.

Ghaffar, Asmahani Mukhtar, 2009. Penerapan PSAK No. 102 tentang Pembiayaan Murabahah pada PT. Bank Syariah Mandiri Cabang Medan. Skripsi. Universitas Sumatera Utara. Medan.

Harahap, Sofyan S., 2012. Teori Akuntansi Edisi Revisi 2011. Cetakan keduabelas. Rajawali Pers. Jakarta.

Kazuraoby, 2011. Bank Syariah. http://kazuraoby.wordpress.com/2011/04/13/70/. Diakses April, 4, 2011.

Kuncoro, Mudrajad, 2009. Metode Riset untuk Bisnis \& Ekonomi. Edisi 3. Erlangga. Jakarta.

Masita ., Jamaluddin., \&Musviyanti, 2013. Analisis Penerapan Pernyataan Standar Akuntansi Keuangan (PSAK) Nomor 102 (STudi Kasus pada Pegadaian Syariah Cabang Gunung Sari Balikpapan. Skripsi. Universitas Mulawarman. Balikpapan. 
Riva, H. Veithzal \& Veithzal, Andria P. 2008. Islamic Financial Management. Cetakan 1. Raja Grafindo Persada.

Supriyanto, 2009. Metodologi Riset Bisnis.

Suwardjono, 2013. Edisi ketiga. Cetakan keenam.Akuntansi Pengantar 1 proses penciptaan data pendekatan system. BPFE-Yogyakarta.

Syariah Mandiri. Murabahah. http://www.syariahmandiri.co.id/category/business-banking/corporatebanking/pembiayaan-corporate-banking/kredit-investasi/murabahah-corporate/.

Syahatah, Husein, 2001. Pokok-Pokok Pikiran Akuntansi Islam.

Warsono, Sony \&Jufri, 2011. Akuntansi Transaksi Syari'ah-Akad Jual Beli di Lembaga Bukan Bank. Penerbit Buku Akuntansi Asgard Chapter.

Widi, Restu Kartiko, 2010. Asas Metodologi Penelitian. Edisi pertama. Cetakan pertama. 